\title{
Institutional (Dis) Incentives to Innovate: An Explanation for Singapore's Innovation Gap
}

\author{
Richard W. Carney and Loh Yi Zheng
}

\begin{abstract}
Despite having the fifth highest per capita GDP in the world (according to IMF PPP statistics for 2007), and despite numerous government efforts to spur innovation, Singapore has faced difficulties in establishing a durable base of entrepreneurial activity. Many ascribe this failure to the city-state's policies, which are often portrayed as generating a culture of risk aversion and a lack of creativity. In contrast to this conventional view, this article argues that the citystate's institutional arrangements generate conflicting innovation incentives and ultimately undermine innovative activity. Statistical tests across twentythree countries offer evidence that is consistent with this argument.
\end{abstract}

KeYwORDS: innovation, varieties of capitalism, institutions, Singapore, technology, technological, politics, research, gross expenditure on research and development, national innovative capacity

nation's institutional arrangements have been pointed to as fostering different types of innovation (Hall and Soskice 2001). The stylized argument is that "patient" financing arrangements (e.g., via concentrated corporate ownership), complemented by stable employment arrangements (which foster the cultivation of job-specific skills), tend to generate more incremental innovations, as in Germany and Japan. "Impatient" financing combined with less stable employment leads toward more "radical" innovations, as in the United States and United Kingdom. Incremental innovation is "continuous but smallscale improvements to existing product lines and production processes," while radical innovation involves "substantial shifts in product lines, the development of entirely new goods, or major changes to the production process" (Hall and Soskice 2001, 38-39). While 
financial and employment arrangements tend to complement one another, it is possible that they do not. For example, if patient financing incentives are combined with unstable employment conditions, innovation will likely be stunted. This article examines the consequences for innovation when noncomplementary institutions generate conflicting incentives, as in Singapore.

Some authors argue that the varieties of capitalism $(\mathrm{VoC})$ perspective overemphasizes the need for complementary institutions to generate successful economic outcomes (Crouch and Farrell 2004), or that hybrid forms of institutional arrangements are not uncommon (Boyer, 2005a, 2005b; Crouch 2005). Because Singapore is unusual among the countries that these studies commonly point to (France and Italy) for the degree to which its institutional incentives conflict, it offers a useful test case. Furthermore, Singapore illustrates the importance of incorporating the state, as an actor in its own right, into an understanding of how varieties of capitalism emerge and persist (Whitley 1996, 2005; Hancké, Rhodes, and Thatcher 2007). Although V. Chibber (2002), Lai Si Tsui-Auch (2004a), and A. Evans (2005) examine the role of the state in jump-starting innovation, they fail to explain why these state-led initiatives often fail to evolve into thriving hubs of self-sustaining innovative activity. Public financing may initiate innovative activity, but our argument is that such endeavors will face difficulties over the long run as a result of the conflicting institutional incentives found in the broader economy.

Other studies question the usefulness of the VoC perspective to explaining innovation (Taylor 2004; Akkermans, Castaldi, and Los 2007). However, these studies focus solely on innovation outputs, as measured by patents or patent citations. This measure of innovation can be problematic, especially among emerging economies or newly industrialized economies because they tend to patent less although they may engage in similar levels of research and development. A better measure in such circumstances, and the one we use, is gross expenditure on research and development (GERD), which measures innovation inputs. GERD is a broader measure of innovation since research and development (R\&D) spending may go toward activities that are not patented, such as copyrights or other in-house innovations that do not wind up being patented with the US Patent and Trademark Office (USPTO). Zoltan Acs and David Audretsch (1988), for example, find that $R \& D$ spending better explains total innovative output than does the number of patented inventions.

It is important to clarify that our investigation focuses on the innovation consequences for Singaporean firms, as opposed to multi- 
national corporations (MNCs) or non-Singaporean firms with facilities in Singapore. This is a necessary distinction to make in the context of such a small, open economy. Our analysis thus remains consistent with the analytical perspective taken in the general $\mathrm{VoC}$ literature, in that institutional effects are examined for their impact on a nation's domestic firms.

We begin the article with a discussion of how institutions foster different types of innovation, which is followed by an examination of how Singapore exhibits conflicting institutional incentives and the consequences for innovation. We then look at cross-national patterns before presenting our conclusions.

\section{Institutions and Innovation}

Firms in coordinated market economies (CMEs) coordinate their economic relationships via close collaboration and incomplete contracting. Those in liberal market economies (LMEs) coordinate their relationships via market competition at arms length. Complementary institutions within CMEs provide a comparative advantage for incremental innovation, which in itself creates obstacles to radical innovation, and vice versa. Because any dichotomous classification entails oversimplification, it is worth noting that the distinction between radical and incremental innovation (and the LME-CME distinction) is a matter of relative degree rather than absolute quality, and conceptual usefulness rather than precision. In this section, we review how complementary institutional arrangements foster different kinds of innovation.

\section{Incremental Innovation}

In coordinated market economies, the presence of controlling shareholders shields firms from short-run capital market pressures, greatly reducing the threat of being taken over in the near term. Managers can focus on long-term productivity growth instead of worrying about consistently meeting quarterly earnings objectives. With a large stake in the company, owners have an interest in ensuring the firm's long-term viability, and they monitor the firm's performance as insiders. They watch the managers to ensure that they do not expropriate profits or other rents and that they do not engage in high-risk activities. With a credible commitment to a long time horizon in place, patient financing ensues. And by being held accountable to the dominant owners for their 
misjudgments, the managers will opt for lower-risk strategies and continuous improvements on established products, focusing on incremental innovation to build a competitive edge over their competitors. Such a strategy requires highly skilled human capital and task-specific physical assets. What such firms lack in flexibility and in terms of implementing high-risk radical changes, they compensate for with technological sophistication and the maintenance of high quality in established products.

But for firms to invest in employees' specialized training, they must be assured not only that poaching of well-trained employees by others is not possible, but also that skilled workers will stay and contribute. Firms that have access to patient capital and that worry less about being taken over can afford to offer long employment tenures and tend to grant a greater voice to their skilled workforce. A dormant external labor market can also help reassure firms of their employees' commitment to their current workplace. Likewise, for firms to invest in specific physical assets, they have to be confident in their long-term arrangements with major suppliers and clients. It follows that an environment that promotes long-lasting and intimate industrial as well as interfirm relationships is crucial for incremental improvements. The prevalence of interlocking directorships and cross-shareholdings in CMEs greatly facilitates the building of informal networks among firms and their owners. Such arrangements foster the cultivation of trust, certainty, and camaraderie throughout the value chain in the case of Japan, or closer sectoral partnership in Germany, both of which are necessary to enforce sanctions for defection of an employee from a firm or for defection of a firm from a collective agreement. This further enables the costs, benefits, and risks of R\&D to be spread among the parties to exploit scale economies and to avoid any duplication of effort. The aim is for everyone to grow in the process, uninterrupted by occasional or cyclical difficulties for individual firms, thereby enabling each party to gain from others' strengths and contributions.

However, for workers to be willing to invest their future in firmspecific training, they must be confident of their job security with the current firm. The perception of being easily replaceable or dispensable does little to provide the incentive for bringing about their full cooperation to innovate. Second, and equally important, the external labor market has to be either nonexistent or unattractive (e.g., punishment for defection), so that workers commit to their current workplace and face fewer incentives to look out for job-hopping opportunities. Ronald Gilson and Mark Roe (1999) explore the institution of lifetime em- 
ployment in Japan along a similar line. Finally, employees need to have some authority over the matters of layoffs, wages, and company decisionmaking. The firms have to let them assume greater responsibility for the firm's success so that workers have a greater stake in it, take pride in it, and commit themselves to the cumulative learning process and to collaboration with other parties for the firm's benefit.

In summary, incremental innovation requires "cumulative learning on the shop floor," where long-tenured workers are equipped with firmspecific skills and require "close long-term inter-firm relationships" throughout boom and bust where suppliers, customers, or industrial associations provide inputs for incremental improvements and there are knowledge spillovers among them (Tylecote and Conesa 1999, 28). Moreover, the focus on incremental innovation is likely to result in firms owning more task- and sector-specific assets. Thus, it follows that the incentive for management to pursue incremental innovation requires a certain pattern of complementary spheres in the labor market, interfirm relations, vocational training systems, and corporate governance.

\section{Radical Innovation}

A fluid labor environment and market-based relationships are important to firms in fast-moving technology sectors facing uncertain market demand. The ongoing hit and miss of new product lines is an essential part of these businesses; firms hope that one blockbuster product can yield rewards that far recover the total costs of unprofitable endeavors. A flexible labor market enables a firm to hire employees with required skills, with the knowledge that they can be dismissed if the project does not materialize. Arms-length relationships also enable firms to quickly acquire a new capability through poaching employees, licensing a new product, or simply buying out a firm with the technology. In these fast-evolving sectors with many uncertainties, speed and flexibility are the keys to survival. As such, the nimbleness of firms requires a concentration of decisionmaking power at the top level of management. They must be able to formulate and implement a new plan, to switch production lines, or to reallocate resources rapidly throughout the enterprise without having the need to seek workers' approval or to justify any drastic action ex ante to the dominant owners. An empowered management is able to divest a subsidiary, close down a whole production line, or shift noncore activities to cheaper places whenever they deem fit; however, such actions almost certainly involve job losses and labor frictions, yet they are necessary prerequisites for company survival in fast-moving industries. 
Unlike situations involving incremental innovation, consensual decisionmaking, both within and between firms, becomes a liability. Radical innovation entails much tacit knowledge and ambiguity. Its merits "cannot be conveyed to any central authority in statistical form." "Man on the spot" - the manager or financier-has to make quick judgments (Hayek 1945, 524). The financiers base many of their decisions on instinct when selecting candidates to support. If the opinions of the labor union, blockholders, and partners are needed, a breakthrough proposal would never get the go-ahead. What keeps the managers in check is the market for corporate control. It pushes them to watch over the shareholders' value at each moment.

Corporate structures that centralize unilateral power in the top management erode any perception of job security in the workforce. It is thus rational for employees and managers to prioritize movable general skills and multipurpose technologies instead of specific ones. Managers tend to have greater autonomy over how the firm is managed when shareholders are dispersed. Due to collective action difficulties, these shareholders usually rely on reputational intermediaries to gather information. It is also often the case that boards of directors are passive, with key members dominated by, or proxies of, the top management. Compared to bank and state financing, a liquid and vibrant equity market is better at coping with novelty and catering to investors with heterogeneous risk appetites. It allows a company to raise capital for a radical proposal where market players hold widely divergent expectations on its profitability. Although the burden of consensus building is avoided, financing in this market can be very impatient and highly volatile.

A thriving venture capital (VC) market is important to the success of technology districts such as Silicon Valley. The VC industry is more developed in stock market-centered systems such as the United States and the United Kingdom than in Japan and Germany. Venture capitalists provide seed and early-stage financing, managerial expertise, and a network of contacts, and they also lend their reputation to start-ups and small and medium-sized enterprises (SMEs). They enable scientists, engineers, and students to bring their ideas to the market. Bank lending is not the traditional source of funds for start-ups, which lack the tangible assets as collateral to secure loans. High-tech start-ups usually have only intellectual property rights to begin with. The VC industry is thus the lifeblood of start-ups and SMEs.

Studies have shown that VC-backed firms perform better than nonVC-backed firms in terms of recording higher sales growth as well as 
job creation (Lee and Wong 2004). Bernard Black and Ronald Gilson (1998) point out that a vibrant stock market that permits venture capitalists to exit through an initial public offering (IPO) is crucial to the vitality of the VC industry. The IPO offers the prospect of an implicit contract for future control by the entrepreneurs as well as a visible benchmark for fund managers' performance to their investors via the IPO price. At the same time, studies of Silicon Valley point to the role of employee mobility between employers and to start-ups in contributing to the incessant waves of radical innovation in high-technology industrial districts (Gilson 1999; Saxenian 1994). The constant flux of knowledge spillovers is critical in building up the momentum of transcending the previous product life cycles. It enables a high-tech cluster to continually renew itself through formation of new firms and new R\&D competencies (Koh, Koh, and Tschang 2003, 12). In addition, Gilson (1999) specifically highlights the nonenforcement in California courts of postemployment covenants not to compete that sustains the self-renewal capabilities in Silicon Valley, in contrast to the lack of vitality on Route 128 in Boston. Employers do not like their employees to use their insider knowledge in competitor firms, but it is prevalent in Silicon Valley. The Economist (1997) terms it "tolerance of treachery," as "secrets and staffs are both hard to keep" there. Occasionally the frustrations of the executives can be seen in the media and lawsuits against former employees. But this involuntary diffusion of tacit knowledge brought about by employee mobility is outweighed by the total benefits of being geographically located in a web of interrelated high-technology entities, sharing the same specialized infrastructure and talent pool (Chiesa and Chiaroni 2004, 3-6; Porter 1998, 213-225). Thus, the development of a VC industry and the existence of autonomous managers share the same prerequisite in a sophisticated stock market. These institutional arrangements, in combination with a fluid labor pool, are conducive to radical innovation.

\section{Singapore: The Consequences of Conflicting Institutional Incentives}

The VoC literature sees complementary institutions as central to the structure of advanced nations' political economies, which in turn foster specific kinds of innovation. Singapore is a truly fascinating case because it defies this logic while being a destination for high-tech companies and having a higher GDP per capita (measured by purchasing 
power parity-PPP) than France, Germany, Japan, and Australia according to the International Monetary Fund (IMF) for 2007. It has the industrial relations arrangements of LMEs while maintaining corporate governance arrangements like those of CMEs. Because it exhibits such conflicting institutional arrangements, it could likely generate many interesting insights on the causes, and consequences, of institutional configurations seen as central to the organization of capitalist systems; here, the focus is on innovation. In the next section, we present the puzzle of innovative stagnation in Singapore; a discussion of the country's corporate governance arrangements, its industrial relations, and its interfirm relationships; and a summary of the consequences for Singaporean innovation.

\section{Singapore's Innovation Problem}

Innovation is a top priority for the Singapore government. A 2002 report by Singapore's Entrepreneurship and Internationalization Subcommittee stresses the importance of entrepreneurship and innovation in transforming Singapore from a capital-driven to an innovationdriven economy. Prime Minister Lee Hsien Loong opened his 2006 Budget Statement by stressing the need for Singapore to become a knowledge hub in Asia, with its future growth fueled by research and development, by value creation through innovation, and by its emergence as a global leader in niche areas. Albert Hu and Shin Jang-Sup $(2002,303)$ explain that Singapore has reached a point where higherend capabilities that are securely based in its territory will increasingly become the determinant of its future growth. As Singapore inches closer to the technological frontier, an innovation strategy built around MNCs becomes less sufficient for catching up, as the "core R\&D capability is the last thing that MNCs will transfer to local subsidiaries." The critical problem is thus the lack of innovation on the part of Singapore-owned firms. In fact, over the years, the government has taken up myriad initiatives in assisting start-ups, has set up research councils and educational programs, and has mobilized a huge amount of resources to this end (see Koh and Koh 2002, 25, Table 7; and Wong et al. 2006, 93-119, for the details of various government policy initiatives and programs). But the push for innovation has so far yielded only disproportionately weak results (Wyatt 2006; Patel 2006). While recent figures for Singapore innovation suggest that it is more innovative than a number of other wealthy countries (according to US patents and GERD), these figures do not accurately depict the situation. Specifi- 
cally, the data do not adjust for the fact that foreign companies in Singapore constitute half of the total $\mathrm{R} \& \mathrm{D}$ spending in the private sector, compared to less than 1 percent in Taiwan and South Korea, let alone other high-income countries (Leung 2006, 106). MNCs employ more researchers than the local companies combined (Agency for Science, Technology and Research 2006, 18, Table 3.2). But instead of seeing MNCs as active innovators, $\mathrm{Hu}$ and Shin $(2002,313)$ argue that this is evidence for weak indigenous innovative capability as well as its small magnitude of activity. As a result, even with a substantial proportion of MNC contribution in patenting activity, Singapore's performance per capita still lags behind other wealthy countries. Moreover, much of the $\mathrm{R} \& \mathrm{D}$ conducted by MNCs is of the later-stage variant and is done more for the purpose of local customization (Koh 2006, 176). The Global Competitiveness Report 2006-2007 points out there is still much room for Singapore to catch up in its firms' capacity for innovation (LopezClaros et al. 2006, 339, 545). A survey on business readiness ranks Singapore the last for "Technology IQ and Innovation" among eleven global cities covered (Price Waterhouse and Coopers and Partnership for New York City 2007, 12).

Prevailing wisdom suggests that local firms, individuals, and culture are to blame for their lack of innovativeness. Singaporeans are portrayed as risk averse; they do not see innovation as part of their jobs, they prefer to work in their comfort zones, they lack the strategic mindset of forming win-win partnerships with other firms, and the command and control structure of firms is stifling. The standard advice is to beef up local firms' awareness of technology, encourage risk taking and creativity, foster closer interfirm partnerships, cultivate more ambitious CEOs and self-driven managers and workers, create an innovationfriendly culture, and so on (Wyatt 2006).

However, the cultural argument has been refuted by Black and Gilson $(1998,271)$ in their observation of successful immigrant entrepreneurs in high-technology ventures (Russians in Israel and Asians in the United States), where the right institutional infrastructure is present. Ho, Koh, and Thangavelu (2002, 339-340) point out that Asian immigrants actually "head one-third of all start-ups in Silicon Valley," and the very creative entrepreneurs among them often come from Asian countries with "very rigid education systems." They doubt the possibility of school curricula and the resulting culture as the main determinants of people's innovativeness. In fact, the IPS-Monitor Group survey finds that within their job scope, Singaporeans are "extremely creative in implementation" (Patel 2006, 49). They are able to achieve 
targets in impressive ways, but they stop short of applying their innovativeness outside their job specifications.

Another forceful exposition against the cultural factor in determining innovativeness is given by Mancur Olson (1996). Again, he uses migration as a natural experiment. Examining data across countries and time, he concludes that institutions and policies are the only decisive factors explaining discrepant country performances across borders. The driving mechanism is the different structure of incentives formed by country-specific institutions and economic policies (Olson 1996, 22).

Viewed from the perspective of its institutional arrangements, Singapore's innovation problems may be due to institutions that give rise to conflicting incentives. Specifically, corporate governance arrangements in Singapore resemble those of CMEs, while its industrial relations are similar to those of LMEs. By picking institutions from different ends of the spectrum, Singapore fails to harness the complementary interactions among them. The contradiction manifests itself in a low level of both incremental and radical types of innovation.

\section{Corporate Governance}

As opposed to the widely held impression of Berle-Means firms in the United States and the United Kingdom, Singapore can be characterized as a combination of family and state capitalism (Tsui-Auch 2004b; Gourevitch and Shinn 2005, 200; Morck and Steier 2005, 46; La Porta, Lopez-de-Silanes, and Shleifer 1999, 492). The state maintains substantial ownership of the corporatized state-owned enterprises as well as a list of wholly owned subsidiaries through its holding companies (Temasek Holdings, MND Holdings, and Health Corporation of Singapore) and statutory boards (Low 2006, 220). The major local firms have controlling shareholders with substantial power over the firms, mainly through pyramidal cascades of companies that accord the ultimate owners the benefits of diversification while retaining control over a large sweep of the economy, or through direct participation in the management. Contests for corporate takeovers are rare in Singapore, much like in Japan and Continental Europe, but in contrast to the United States and the United Kingdom (Wang, Qi, and Wong 2002, 16; Financial Times 2007). The difference with Japan and Europe is that poison pill and dual-class shares are not used in Singapore. Its company law provides for and enforces a oneshare, one-vote rule. Nonetheless, the pyramidal structure of ownership achieves the same end in the control of firms as dual-class shares (The Economist 2007; La Porta, Lopez-de-Silanes, and Shleifer 1999). More- 
over, the state's practice of informal guide over mergers and acquisitions (M\&A) transactions could also have dented the frequency of takeovers (Economist Intelligence Unit 2006, 18-19; Gourevitch and Shinn 2005, 201).

Owners hold the decision of key managerial appointments, set the strategic directions of firms, and monitor performance as insiders. An amendment to the Companies Act in 2003 explicitly provides that "the business of a company shall be managed by or under the direction of the directors." In Singapore, the Directorship and Consultancy Appointments Committee (DCAC) under the Ministry of Finance appoints the boards of directors among the government-linked companies (GLCs) from the civil service, and increasingly from the private sector. Linda Low $(2006,217)$ observes that "cross-interlocking directorships among a few top, trusted bureaucrats who are in the inner circle of decisionmakers, is not uncommon." As in bank capitalism in Japan and Germany, this preponderant presence of private blockholders and the insulation of firms from hostile takeovers result in the provision of patient capital. This ownership structure is viewed as beneficial to innovation, as explained by Prime Minister Lee: "R\&D requires long-term commitment. To develop new capabilities, we must support projects on a sustained basis, buffering them from the vagaries of year to year budgetary pressures, and judging results over several years" (Budget Statement 2006). As a result, firms become less sensitive to current profit levels and aim for long-term profitability and growth. In the words of Randall Morck and Lloyd Steier (2005), the managers are "hired help," subservient to the powerful family owners and the state. As such, they do not possess the unilateral decisionmaking power of their counterparts in the United States and the United Kingdom, who generally have dispersed shareholders and largely passive boards of directors to deal with.

Much in line with Japan and Germany, where banks perform the job of insider monitoring and provide long-term financing, the incentive for managers in Singapore is to avoid breaking with the past in corporate strategies. And what's more, the cadre of professional managerbureaucrats who move back and forth between the private sector and the civil service plays a significant role in the management of GLCs in Singapore. Being accountable to the state or family blockholders for their mistakes, and faced with the impossibility of communicating an innovation's appeal to their higher authorities (due to ambiguous evidence for its potential, which also involves much tacit knowledge the more radical it is), the managers will avoid very novel kinds of projects (Phelps 2006, 11; Hayek 1945, 524). Instead, together with the incen- 
tive provided by patient capital, they will opt for lower-risk incremental improvements on established products, developing a market niche, maintaining quality while holding down costs, and fine-tuning the existing technologies.

An additional problem for supporting radical innovation in Singapore is that the capital market is relatively small, with only latent M\&A activities (Wang, Qi, and Wong 2002, 16). The SESDAQ market, Singapore's equivalent of NASDAQ and AIM, has yet to attract the firms and investors that were initially intended (Bruton, Ahlstrom, and Singh 2002, 211). This renders the exit mechanism via capital market more difficult than in the United States and the United Kingdom. It limits the size and development of VC industry in Singapore. The frustration in an interviewee's response in the survey conducted by Garry Bruton, David Ahlstrom, and Kulwant Singh $(2002,211)$ is most telling: "The problem here is that the public equity market is not structured in a way that it really facilitates using exits for these venture firms.... It is still a pretty tough uphill struggle. ... [The] ability to exit from of one of these start-up investments is much more difficult than you will find in the US and enough to cause you problems."

As a result, the amount invested locally averages merely US $\$ 2$ million each deal compared to US\$13.2 million in the United States, and they are typically not at the seed stage (Koh 2006, 191; Koh and Koh 2002, 20; EISC 2002, 30). Singapore has succeeded, as a first step, in wooing foreign $\mathrm{VC}$ funds to set up regional operation here. But thus far more than 85 percent of the funds managed in Singapore are invested overseas (Bruton, Ahlstrom, and Singh 2002, 202). For the year 2004, Singapore was ranked seventeenth out of twenty-one Organization for Economic Cooperation and Development (OECD) countries in VC funding intensity (local VC investment/GDP), ahead of Japan and Germany but below the mean score of all countries (Wong et al. 2006, 35). An active SESDAQ would help much in the maturity of a domestic VC market, and potentially in igniting local SMEs in the manufacturing sector as they face very fierce competition by MNCs (Ho, Koh, and Thangavelu 2002, 340; Patel 2006, 59; EISC 2002, 18).

\section{Industrial Relations}

The labor market in Singapore is highly fluid. There is no law prohibiting the firing of workers and no minimum wage. The Global Competitiveness Report finds Singapore the second easiest place in the world to hire and fire, just behind Zambia-in other words, the easiest 
among the more developed countries (Lopez-Claros et al. 2006, 485). These conditions are hailed as critical for attracting foreign direct investment. The government holds considerable discretion in determining the supply and costs of labor-for example, through setting the Central Provident Fund (CPF) contribution rate or adjusting the quota of foreign workers, which is kept secret from the people and from labor (Bhaskaran 2003; Low 2006, 376).

Trade union movements are brought under the aegis of the National Trades Union Congress (NTUC), led by a technocratic elite co-opted by the government with a cabinet post (Khong 1995, 122). "The NTUC's purpose appears to be to explain government policy to union members and mobilize their support behind government initiatives. The wagenegotiating function . . . has been appropriated by the National Wages Council, which meets in close-door sessions with employers and government" and releases recommendations on wage changes. A 1983 amendment of the Trade Unions Act has broken up large unions into industry-based unions, and then into small in-house unions with management participation. An incident of voting out in 2003-by the Airline Pilots' Association of Singapore (Alpa-S) of its entire executive for being seen as siding too much with management in a deal-prompted the government to amend again the Trade Unions Act. It "remove[s] the need for its elected leaders to seek members' approval before concluding collective agreements or settling disputes with management" (Straits Times 2004; Financial Times 2003; Rodan 2006, 157). The government later revoked a pilot's twenty-six-year permanent residency status as a punishment for instigating the campaign and as a reminder of the consequence for other union militants. Thus, the tripartism in Singapore, much lauded by its leaders despite the conspicuous top-down features (Straits Times 2007; Budget Statement 2006, 2), differs markedly from the tripartism in other small and corporatist OECD countries such as Switzerland and Austria (Katzenstein 1984).

In Singapore, the market for managers and workers is competitive, with high turnover. The flexible labor market resembles that of the United States and the United Kingdom with its generally short job tenures. The fluid labor market in Singapore is more conducive to radical innovation but counterproductive for incremental innovation. It is crucial for firms in fast-moving technologies to be able to dispose of workers with less relevant skills and to hire new workers as the need arises. Similar to the United States and the United Kingdom, the education system in Singapore equips workers with applicable general and marketable skills, preparing them for the capricious employment setting. 
Schemes such as the Skills Development Fund, the Lifelong Learning Endowment Fund, and the Manpower Development Assistance Scheme are tasked to cosubsidize workers' training with firms to maintain their general employability, as firms tend to underinvest in human capital in a fluid labor market where poaching of employees is common.

Furthermore, a Citigroup report on dual economy finds that foreigners constitute a higher proportion of the labor force in the highgrowth external demand sectors in Singapore (Chua 2006, 3), which predictably pertain more to technological innovation. In the right environment, the experience of Silicon Valley shows that foreign entrepreneurs can play a major role in the development of a technology district, creating jobs and growth (Saxenian 1999). Besides, the expatriate managers, engineers, and scientists on the whole are expected to stay in Singapore for a short span, which is inconsistent with the long-term commitment necessary for incremental innovation. On the contrary, incremental innovation requires that workers be "skilled enough to come up with such innovations, secure enough to risk suggesting changes . . . that might alter their job situation, and endowed with enough work autonomy" to see the innovations as part of their jobs (Hall and Soskice 2001, 39). Both kinds of innovation require totally opposite labor environments. Also, job insecurity in fluid labor markets makes it more likely for the workers to prioritize movable general skills instead of committing to firm-specific skills. Personal career comes first, rather than the firm's success.

\section{Interfirm Relationships}

As in the United States and the United Kingdom, firms in Singapore deal with each other at arm's length, and their relationships are largely dictated by price signal. A survey conducted by the Institute of Policy Studies (IPS) and the Monitor Group finds that even where interfirm partnerships exist, they are predominantly transactional in nature mainly to fill the competency gaps (Patel 2006, 49). Singapore's similar contract laws and legal environment with the United States and the United Kingdom tend to discourage deep and meaningful interfirm collaboration as well. The same survey reveals that companies working on the same project do not actively "share information and expertise beyond what is necessary for a particular project" (Patel 2006, 53). This is not unexpected. Technological diffusion in LMEs is usually through licensing, staff movements, or M\&A activities. This market-based environment renders employees' movements between firms easier and more ac- 
ceptable, compared to the industrial associations in Germany and rival group firms in Japan. In the relationship-based settings there, parties to an agreement have the capacity to sanction any defection from cooperative behavior.

\section{Summary}

Several issues for Singapore should be clear by now. Employees are mobile, with job tenure generally short-lived. Poaching of employees by other firms is very common. Head-hunting activities here are thriving, like in the United States and the United Kingdom. Firms deal with each other at arm's length. Economic relationships are largely coordinated by market competition - if they come too close, they unnecessarily run the risk of arousing suspicion of the regulators. It is natural for them to stay on the safe side, even in a partnership. In addition, without a credible mechanism in place to sanction defection, the signal for mutual commitments among the market players is weak. Therefore, government initiatives such as the Local Industry Upgrading Program are not likely to bear long-term fruit beyond the level of noncore technology transfer and the later-stage, local-customization part of R\&D collaboration.

Moreover, workers in Singapore are weaker than those in CMEs, resulting in job insecurity and a flexible labor market. They do not have as much say in the running of firms. It is little wonder that workers do not go the extra mile to be innovative, preferring to fulfill their tasks as specified (Patel 2006, 49). Unlike those in Japan and Germany, the employment and welfare of workers in Singapore are less tied to a firm. They are not as pressed to ensure a firm's superior performance over others. Hence, although firms in Singapore have controlling shareholders and patient capital, which incentivize the management to pursue incremental innovation, the incentives for workers' long-term commitment, for interfirm collaboration, and for both to acquire specific assets are all but absent. Therefore, conflicting incentives as a result of incompatible institutions bring neither incremental nor radical innovation to Singapore.

\section{Cross-National Patterns}

E. C. Ernst (2004) examines the consequences of complementarity between corporate governance and industrial relations for firms' output growth. He examines twenty-seven manufacturing industries in nineteen 
OECD countries from 1970 to 1995 and finds that concentrated ownership structures, when combined with high employment protection, produce higher growth in industries that require close stakeholder coordination, as measured by the demand for input of skilled labor and bank financing. At the same time, financial relations marked by market liquidity and dispersed ownership, when combined with a flexible labor market, lead to higher growth in industries with high equity demand. Tested individually, the results are ambiguous.

\section{Selection of Data and Variables}

Ernst's findings lend strong support to the complementarity thesis, particularly with regard to sectoral value-added growth. However, the range of indicators that he employs for financial structure and the labor market are available only for the nineteen OECD countries, and they are averages that go as far back as 1970. It would be preferable to conduct tests that incorporate the four Asian newly industrialized economies (NIEs) Singapore, Hong Kong, Taiwan, and South Korea — as emerging wealthy nations, because they can serve as a useful comparison to Singapore, and because they are important to Asia's economic growth. Furthermore, innovation is very much relevant to them at this stage as they move up closer to the technological frontier. Indigenous technological capability will increasingly be the propeller of their future growth, compared to the role that imitation and catching up played in the past. In the 1970s, they were still at the early stages of development; only in the 1990s did their transition from investment-driven to innovation-driven growth start to take shape. A felicitous comparison of the institutional impact on innovation that comprises both the advanced countries and the NIEs should therefore use recent data, preferably from after the Asian financial crisis.

\section{Dependent Variable}

Accurately measuring the level of innovation in a country is difficult. While frequently used, patenting activity can be problematic as a measure for innovation. It provides a visible outcome for innovative activity, but not all inventions are patentable and not all patentable inventions are patented. It is also probable that industries differ in patenting intensity. Given sector specialization in different countries, inferences from the number of patents granted can be misleading. After all, not all patents are equally important, and older patents have more time to be cited than newer ones. Moreover, the more radical and breakthrough 
types of discoveries are expected to be more heavily cited than incremental ones. It makes the importance of a patent hard to define.

Another commonly used indicator for innovative capability is the ratio of gross expenditure on R\&D to GDP. Though it measures the efforts put into innovative activity rather than outcomes, it is representative of and thus comparable across all countries and different types of innovative activity. GERD is also a broader measure of innovation, since $R \& D$ spending may go toward activities that are not patented, such as copyrights or other in-house innovations that do not wind up being patented with the USPTO. Acs and Audretsch (1988), for example, find that $R \& D$ spending better explains innovative output than does the number of patented inventions. Thus, for the indicator of innovative capability, we take the ratio of GERD to GDP across twentythree countries from the World Development Indicators (WDI). ${ }^{1}$ The definition of the variable as provided by the WDI is "Expenditures for research and development [include] current and capital expenditures (both public and private) on creative work undertaken systematically to increase knowledge, including knowledge of humanity, culture, and society, and the use of knowledge for new applications. R\&D covers basic research, applied research, and experimental development."

We use the average for the years 2000-2006 (the most recent data available). By 2000, countries in East Asia had generally recovered from the financial crisis, making it a useful starting point for assessing standard levels of GERD. We investigate only the more developed economies, since their institutions are mature and thus are likely to meaningfully influence innovative activity and to be comparable to other advanced industrialized states. But it is important to note that the limited number of country observations makes the Singapore case study an important supplement to the statistical analysis.

\section{Independent Variables}

We test the argument that complementary interactions between a concentrated ownership structure and a more rigid labor market foster innovation; where these institutions are noncomplementary, less innovation is expected. For the measure of ownership concentration, we take the blockholding index compiled by Peter Gourevitch and James Shinn (2005, 299-300) from various sources. The index is a figure from 0 to 100 that represents the market value of all the listed firms controlled by an individual blockholder as a proportion of the total stock market capitalization in a country. For the indicator of labor market flexibility, 
we use the rigidity of employment index from the World Bank's Doing Business database. The index also ranges from 0 to 100 , indicating the difficulty in hiring, firing, and changing the working hours, with a higher value indicating more rigid regulations (see Table 1).

A scatterplot of the blockholding index and rigidity of employment index reveals a positive association, as shown in Figure 1. The LMEs (the United States, the United Kingdom, Australia, Canada, and New Zealand) cluster at the bottom left, while the CMEs (Germany, Italy, Sweden, Austria, and France) anchor the top right corner.

Japan's very low blockholding index (of 4.1) may seem surprising in view of the extensive cross-shareholdings among keiretsu firms on the Tokyo Stock Exchange. Gourevitch and Shinn (2005, 18-19) explain that the indicator reflects the nominal shareholding of firms. When the network of ownership is traced, there are only very few instances where an individual or a family holds a substantial ownership in a firm. They acknowledge the limit to the accuracy of this index in revealing the control of firms in the case of Japan. In addition, Morck and Steier $(2005,14)$ note that "even though each firm holds only a tiny stake in every other firm, these stakes collectively sum to effective control blocks. Every firm in the keiretsu group is thus controlled collectively by all the other firms in the group." Thus, we should note that if we corrected for this, the statistical results would likely be stronger (though they are still strongly supportive of the hypothesis).

To measure how well blockholding and employment rigidity complement one another, we take the orthogonal distance of a country from the best fit line in Figure 1. We use orthogonal distance rather than the interaction, or the absolute value of the difference, of the two variables. The interaction of the two variables can be misleading, since a low and a high value, when interacted, may equal the interacted value of two medium values; however, we expect the latter, rather than the former, to foster more innovative activity. The absolute value of the difference between the variables can also be misleading since, although both measures range from 0 to 100 , the maximum values and the means differ by about 10-15 points. Such a large difference would suggest a lack of complementary institutions, while in fact they may be highly complementary. The difference is simply due to the way the measures are constructed. Thus, the orthogonal distance from the best fit line offers a simple and reasonable way to capture the essence of what we are trying to measure. The farther away from the best fit line, the less complementary 


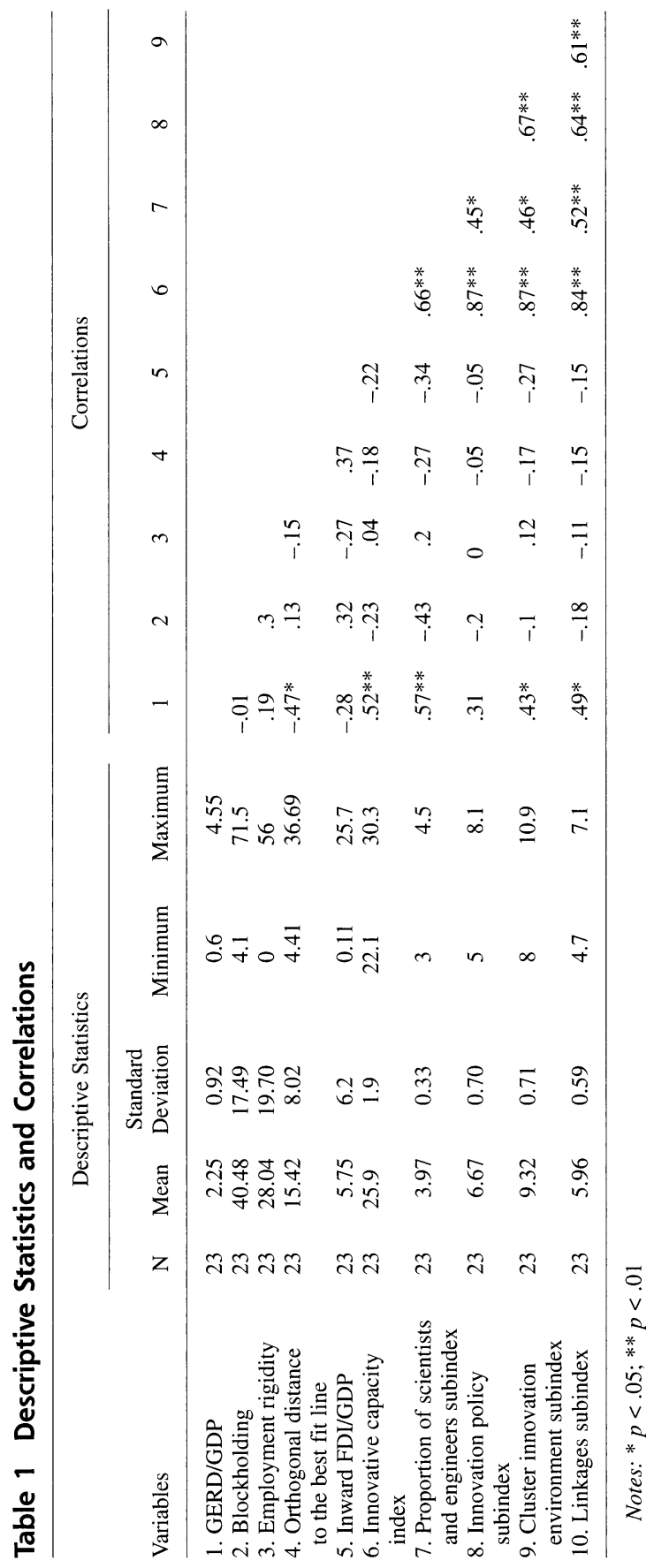


Figure 1 Scatterplot of Blockholding Index and Employment Rigidity

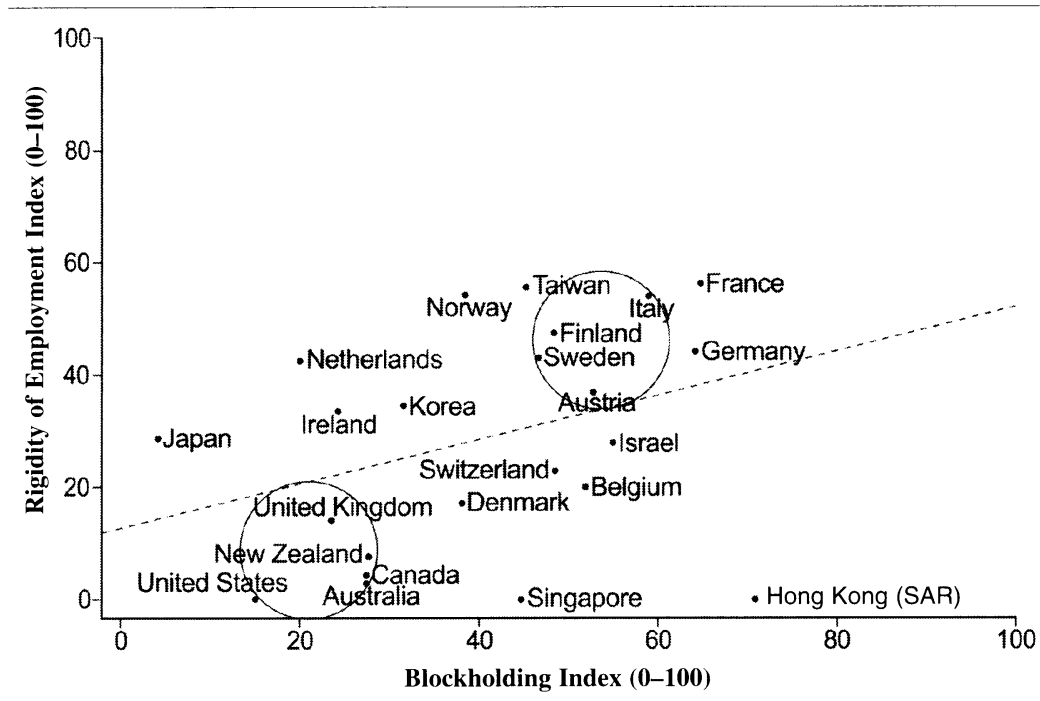

are the institutions in relation to other countries at a similar level of development, and thus of similar technological capabilities.

A comprehensive account of national innovativeness is presented by J. L. Furman, M. E. Porter, and S. Stern (2002). They develop a national innovative capacity framework that draws on three distinct areas of prior research: ideas-driven endogenous growth theory (Romer 1990), the cluster-based theory of national industrial competitive advantage (Porter 1990), and research on national innovation systems (Nelson 1993). Each of these perspectives identifies country-specific factors that determine the flow of innovation. Porter and Stern (2001) present country indexes corresponding to these inputs to national innovativeness, which we use in our tests. We control for income differences by restricting the sample to wealthy countries, and we control for the potential biasing effects on domestic research and development resulting from inflows of foreign direct investment by controlling for this variable as well (with the average for 2000-2006 for each country, mirroring the dependent variable). ${ }^{3}$

\section{Results}

In Table 2, we show the results of five regression models. In model 1, we test the direct effect of the two individual independent variables to 


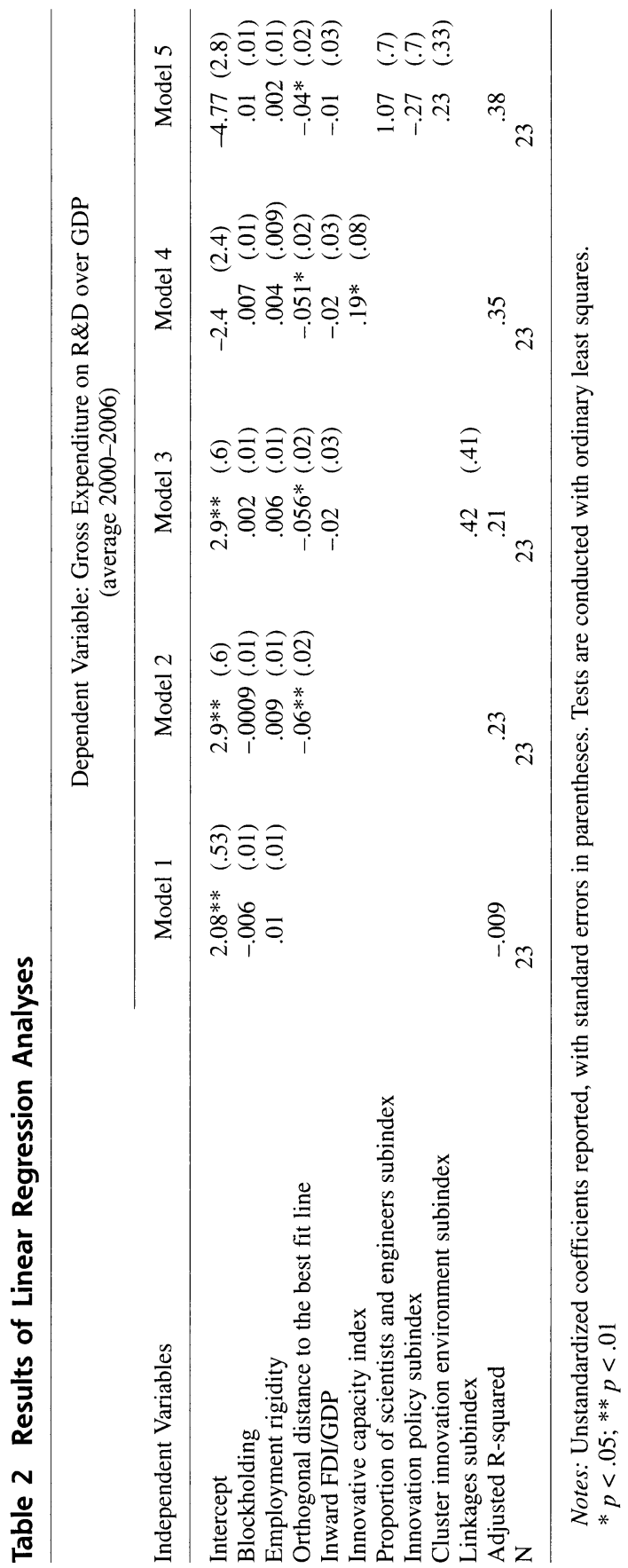


check whether corporate governance or industrial relations can individually explain the level of innovation. The coefficients are statistically insignificant, as expected. Model 2 tests for whether innovation is higher (lower) when these institutions complement (diverge from) one another. The results support this contention, as the coefficient for the orthogonal distance is significant at the 1 percent level, and it is negative, indicating that the more that institutions diverge from the best fit line (i.e., the less complementary they are in comparison to other wealthy countries), the less innovation that occurs.

Model 3 tests for whether the results are robust to inflows of foreign direct investment, which they are. Model 4 controls for a nation's innovative capacity with the innovative capacity index presented by Porter and Stern (2001). In this test, the innovative capacity index is positive and statistically significant at the 5 percent level (as expected), and the orthogonal distance remains statistically significant at the 5 percent level. By including both of these variables, the adjusted $\mathrm{R}$-squared value increases from 0.21 , when only the orthogonal distance variable is included, to 0.35. Model 5 controls for the variables that comprise the innovative capacity index. In this case, the subindexes add little explanatory power to the gross expenditures on $\mathrm{R} \& \mathrm{D}$ as displayed by the small increase in the adjusted R-squared value from 0.35 in model 4 , to 0.38 . The orthogonal distance variable retains its statistical significance at the 5 percent level.

\section{Conclusion}

We see a range of implications, including some avenues for future research on varieties of capitalism, ideas of importance to the policy arena, and managerial implications. We discuss each in turn.

Recent work in the varieties of capitalism research stream has specifically pointed to the need for incorporating a distinct role for the state (e.g., Hancké, Rhodes, and Thatcher 2007). While France stands out among countries conventionally examined for the state's influence, and likewise for its mixed market economy, Singapore is an even more dramatic case of state intervention and hybrid institutions. We wonder if the similarities between these two cases in terms of the existence of a strong state and hybrid outcomes is more than coincidence-that is, whether hybrid forms are more likely to arise in the presence of a strong state (where the state has motives that are independent of social 
and economic interests). This appears to be a promising area for further research.

We further wonder whether, when institutional arrangements emerge from bargains struck among domestic economic and social interests, they are more likely to be part of a broad, coherent institutional bargain and thus more likely to exist in democratic settings. For example, Thomas Cusack, Torben Iversen, and David Soskice (2007) argue that proportional representation has helped to preserve a coordinated market economy because it grants political power to numerous economic actors with mutual interests in sustaining the coordinated economic system. But in nonedemocratic settings, institutions may be designed more as a result of elites' interests, which may differ from those of social and economic interests. This can grant greater scope for the existence of noncomplementary institutions so long as such arrangements achieve some desired objective on the part of the elites. By restricting the focus to democratic states, prior studies on national innovativeness and varieties of capitalism may not pick up a discernible impact on innovation. This suggests that research on varieties of capitalism must be expanded not only to incorporate a role for the state, but also to account for the level of democracy. We see this as a second area worthy of research, particularly in light of the growing importance of China's economy.

With regard to policy implications, policymakers in a young country may pick and modify different best practices from different successful countries and expect the end product to be at least as good as the summation of its components. But institutions in different spheres interact with each other. This synergy of complementary institutions is often overlooked. The total will exceed the summation of its parts if their incentives complement. If the incentives contradict, the total will be less. Institutional arrangements are foundational as they shape and give rise to systemic incentives throughout the economy. Thus, in addressing the problem of lack of innovativeness, policymakers should examine the institutions in place and their interaction.

The Singapore government may continue to improve the situation with piecemeal strategies, but the consequences for overall innovative activity will not likely be impressive. This article argues that institutions that generate conflicting incentives will ultimately undermine the government's initiatives. It is problematic to search for one best form of organization or to benchmark individual best practices from various countries. Each choice involves a trade-off. Each "best form" comes at 
the expense of something else. We should be aware of the interplay of institutions and whether they complement or contradict.

Rather than putting "pressure on GLC management to foster innovation," as prescribed by a recent survey (Patel 2006, 59), one solution following the arguments in this article suggests that the government release pressure on them instead and, if possible, take steps to divest its stakes in the GLCs. If a vibrant and liquid stock market results, the overall environment would be more conducive to radical innovation. Alternatively, the government could bolster employment stability and thereby encourage incremental innovation. But both choices entail political costs. Divestiture of ownership stakes would require that Temasek Holdings give up control over the small country's private sector-indeed, the heart and soul of the city-state. This may allow other businesspeople, whose interests may not be aligned with Singapore's bureaucratic elite, to have a greater say over the governance of the city-state's economy. But promoting employment stability could also be difficult, since it may discourage foreign direct investment and could open the door to more cohesive and influential labor groups at the firm level.

Finally, with respect to managerial implications, managers of domestic firms need to recognize the broader institutional constraints within which their firm operates and promote innovative activities that correspond to them. Indeed, the Singapore case illustrates the difficulties of spurring innovation when the institutional incentives conflict. The lessons are most appropriate for managers working in high-technology sectors, and particularly in the newly industrialized economies where such technological comparative advantage arising from institutional arrangements may not yet be fully recognized (e.g., Singapore, Hong Kong, Taiwan, and South Korea). Understanding the institutional constraints gives managers a better understanding of what types of $R \& D$ to engage in, depending on the country context. Among the NIEs in East Asia, Taiwan and South Korea appear to have the most complementary institutional arrangements for innovation, though they are mainly of the incremental variety. Neither Singapore nor Hong Kong seems to have the necessary complementary institutional arrangements to build a durable base of innovation of either style.

Richard Carney is assistant professor at the S. Rajaratnam School of International Studies in Singapore. He is the editor of a forthcoming book, Lessons from the Asian Financial Crisis, and the author of another forthcoming book, Contested Capitalism: Political Origins of Financial Institutions. Loh Yi Zheng is a business analyst with Singapore Post. He was previously employed 
by Sony Electronics Asia Pacific and is a graduate of the Nanyang Business School and of the S. Rajaratnam School of International Studies.

\section{Notes}

1. Sample countries (2000-2006) include Australia, Denmark, Hong Kong, Japan, Norway, Taiwan, Austria, Finland, Ireland, South Korea, Singapore, United Kingdom, Belgium, France, Israel, Netherlands, Sweden, United States, Canada, Germany, Italy, New Zealand, and Switzerland. Data for Taiwan come from the Government Information Office website, Republic of China (www.gio.gov.tw/ct.asp?xItem $=35664 \&$ ctNode=2591).

2. One problem with this indicator is that it is does not distinguish between domestic and foreign sources of research and development. As noted in the earlier section on Singapore's innovation problems, the city-state is unusual in that around 50 percent of total R\&D spending is done by MNCs, compared to 1 percent for other comparable countries such as South Korea and Taiwan. Because our focus is on the capacity for domestic firms to innovate, we adjust the measure for Singapore accordingly.

3. Data for FDI inflows come from the World Bank. FDI inflows for Taiwan come from the UN Conference on Trade and Development (UNCTAD).

\section{References}

Acs, Zoltan J., and David B. Audretsch. 1988. "Innovation in Large and Small Firms: An Empirical Analysis." American Economic Review 78, 4: 678-690. Agency for Science, Technology and Research (A*STAR). 2006. "National Survey of R\&D in Singapore 2005." Singapore: A*STAR.

Akkermans, Dirk, Carolina Castaldi, and Bart Los. 2007. "Do 'Liberal Market Economies' Really Innovate More Radically Than 'Coordinated Market Economies'? Hall and Soskice Reconsidered.” Research Memorandum GD-91. Groningen: Groningen Growth and Development Centre.

Bhaskaran, Manu. 2003. Re-inventing the Asian Model: The Case of Singapore. Singapore: Institute of Policy Studies.

Black, Bernard S., and Ronald J. Gilson. 1998. "Venture Capital and the Structure of Capital Markets: Banks Versus Stock Markets." Journal of Financial Economics 47: 243-277.

Boyer, Robert. 2005a. "Complementarity in Regulation Theory." SocioEconomic Review 3, 2: 366-371.

. 2005b. "How and Why Capitalisms Differ." Economy and Society 34, 4: 509-557.

Bruton, Garry D., David Ahlstrom, and Kulwant Singh. 2002. "The Impact of the Institutional Environment on the Venture Capital Industry in Singapore." Venture Capital 4, 3:197-218. 
Budget Statement. 2006. Ministry of Finance, Singapore.

Chibber V. 2002. "Bureaucratic Rationality and the Developmental State." American Journal of Sociology 107, 4: 951-989.

Chiesa, Vittorio, and Davide Chiaroni. 2004. Industrial Clusters in Biotechnology: Driving Forces, Development Processes and Management Practices. London: Imperial College Press.

Chua, Hak Bin. 2006. "Singapore: A Dual Economy?” Citigroup Global Markets Singapore Pte. Ltd.

Crouch, Colin. 2005. Capitalist Diversity and Change: Recombinant Governance and Institutional Entrepreneurs. Oxford: Oxford University Press.

Crouch, Colin, and Henry Farrell. 2004. "Breaking the Path of Institutional Development? Alternatives to the New Determinism." Rationality and Society 16, 1: 5-43.

Cusack, Thomas, Torben Iversen, and David Soskice. 2007. "Economic Interests and the Origins of Electoral Systems." American Political Science Review 101, 3: 373-391.

Economist. 1997. "What It Takes to Come Top in Technology: Vital Intangibles." A Survey on Silicon Valley. March 29.

Economist Intelligence Unit. 2006. Main Report. Country Commerce Singapore.

EISC (Entrepreneurship and Internationalisation Subcommittee) Report. 2002. Economic Review Committee, September 13, Singapore.

Ernst, E. C. 2004. "Financial Systems, Industrial Relations, and Industry Specialization: An Econometric Analysis of Institutional Complementarities." In Proceedings of the First OeNB Workshop. Vienna: Osterreichische Nationalbank.

Evans, A. 2005. "Preemptive Modernisation and the Politics of Sectoral Defense: Adjustment to Globalisation in the Portuguese Pharmacy Sector." Mimeo.

Financial Times. 2003. "Singapore Cracks Down on Airline Pilots' Union." December 2.

—. 2007. "Brussels Threat to Reform Takeover Laws." February 27.

Furman, J. L., M. E. Porter, and S. Stern. 2002. "The Determinants of National Innovative Capacity.” Research Policy 31: 899-933.

Gilson, Ronald J. 1999. "The Legal Infrastructure of High Technology of Industrial Districts: Silicon Valley, Route 128, and Covenants Not to Compete.” New York University Law Review 74, 3: 575-629.

Gilson, Ronald J., and Mark J. Roe. 1999. "Lifetime Employment: Labor Peace and the Evolution of Japanese Corporate Governance." Columbia Law Review 99: 508-540.

Gourevitch, Peter, and James Shinn. 2005. Political Power and Corporate Control: The New Global Politics of Corporate Governance. Princeton: Princeton University Press.

Hall, Peter, and David Soskice. 2001. Varieties of Capitalism: The Institutional Foundations of Comparative Advantage. Oxford: Oxford University Press.

Hancké, Bob, Martin Rhodes, and Mark Thatcher. 2007. Beyond Varieties of Capitalism: Conflict, Contradictions, and Complementarities in the European Economy. New York: Oxford University Press. 
Hayek, Friedrich A. 1945. "The Use of Knowledge in Society." American Economic Review 35, 4: 519-530.

Ho, Kong Weng, Koh Ai Tee, and Shandre Thangavelu. 2002. "Enhancing Technopreneurship: Issues and Challenges." In Singapore Economy in the 21st Century: Issues and Strategies, ed. Koh Ai Tee. Singapore: McGraw Hill.

Hu, Albert G., and Shin Jang-Sup. 2002. "Climbing the Technology Ladder: Challenges Facing Singapore in a Globalized World." In Singapore Economy in the 21st Century: Issues and Strategies, ed. Koh Ai Tee. Singapore: McGraw Hill.

Katzenstein, Peter. 1984. Corporatism and Change: Austria, Switzerland, and the Politics of Industry. Ithaca: Cornell University Press.

Khong, Cho-Oon. 1995. "Singapore: Political Legitimacy Through Managing Conformity." In Political Legitimacy in Southeast Asia: The Quest for Moral Authority, ed. Muthiah Alagappa. Stanford: Stanford University Press.

Koh, Francis C. C., and Winston T. H. Koh. 2002. "Venture Capital and Economic Growth: An Industry Overview and Singapore's Experience." Singapore Management University Economics and Statistics Working Paper No. 21-2002.

Koh, Francis C. C., Winston T. H. Koh, and Feichin Ted Tschang. 2003. “An Analytical Framework for Science Parks and Technology Districts with an Application to Singapore." Singapore Management University Economics and Statistics Working Paper No. 18-2003.

Koh, Winston T. H. 2006. "Towards Innovation-driven Economic Growth: R\&D Capabilities and Entrepreneurship in Singapore." In The Economic Prospects in Singapore, ed. Winston Koh and Robert Mariano. Singapore: Pearson Addison Wesley.

La Porta, Rafael, Florencio Lopez-de-Silanes, and Andrei Shleifer. 1999. "Corporate Ownership Around the World." Journal of Finance 14, 2: 471-517.

Lee, Lena, and Poh-Kam Wong. 2004. "Venture Capital in Singapore." National University of Singapore Entrepreneurship Centre Working Paper 2004-19.

Leung, Hing Man. 2006. "Industrial Policy and Economic Development: Comparing Singapore with Hong Kong, Korea and Taiwan." In The Economic Prospects in Singapore, ed. Winston Koh and Robert Mariano. Singapore: Pearson Addison Wesley.

Lopez-Claros, Augusto, Michael E. Porter, Xavier Sala-i-Martin, and Klaus Schwab. 2006. Global Competitiveness Report 2006-2007: Creating an Improved Business Environment. Basingstoke, UK: Palgrave Macmillan.

Low, Linda. 2006. The Political Economy of a City-State Revisited. Singapore: Marshall Cavendish Academic.

Morck, Randall, and Lloyd Steier. 2005. "The Global History of Corporate Governance: An Introduction.” NBER Working Paper 11062. Cambridge, MA: National Bureau of Economic Research.

Nelson, R. R., ed. 1993. National Innovation Systems: A Comparative Analysis. Oxford: Oxford University Press. 
Olson, Mancur. 1996. "Distinguished Lecture on Economics in Government: Big Bills Left on the Sidewalk: Why Some Nations Are Rich, and Others Poor." Journal of Economic Perspectives 10, 2: 3-24.

Patel, Hitendra. 2006. "The State of Innovation in Singapore: Study Presentation." In The Fifth Singapore Economic Roundtable. Singapore: SNP Reference for Institute of Policy Studies.

Phelps, Edmund S. 2006. "Toward a Model of Innovation and Performance Along the Lines of Knight, Keynes, Hayek and M. Polanyi." Prepared for the Conference on Entrepreneurship and Economic Growth, Max-Planck Institute and the Kauffman Foundation.

Porter, M. E. 1990. The Competitive Advantage of Nations. New York: Free Press.

1998. On Competition. Boston: Harvard Business School Press.

Porter, M. E., and S. Stern. 2001. National Innovative Capacity. The Global Competitiveness Report, 2001-2002. New York: Oxford University Press.

Price Waterhouse and Coopers and Partnership for New York City. 2007. "Cities of Opportunity: Business-Readiness Indicators for the 21 st Century." Available at www.pwc.com/cities.

Rodan, Garry. 2006. "Singapore: Globalisation, the State and Politics." In The Political Economy of South-east Asia: Markets, Power and Contestation. 3rd ed., ed. Garry Rodan, Kevin Hewison, and Richard Robison. Oxford: Oxford University Press.

Romer, P. 1990. "Endogenous Technological Change." Journal of Political Economy 98: 71-102.

Saxenian, AnnaLee. 1994. Regional Advantage: Culture and Competition in Silicon Valley and Route 128. Cambridge: Harvard University Press.

- 1999. Silicon Valley's New Immigrant Entrepreneurs. San Francisco: Public Policy Institute of California.

Straits Times. 2004. "Why Amend Act? Alpa-S Saga Shows Workers' Interests Not Protected." April 21.

. 2007. "A Singapore Secret That Cannot Be Easily Copied." January 25.

Taylor, M. Z. 2004. "Empirical Evidence Against Varieties of Capitalism's Theory of Technological Innovation." International Organization 58: 601-631.

2007. "Family Capitalism: Our Company Right or Wrong." March 17.

Tsui-Auch, Lai Si. 2004a. "Bureaucratic Rationality and Nodal Agency in a Developmental State: The Case of State-led Biotechnology Development in Singapore." International Sociology 19, 4: 451-477.

_. 2004b. "The Professionally Managed Family-ruled Enterprise: Ethnic Chinese Business in Singapore." Journal of Management Studies 41, 4: 693-723.

Tylecote, Andrew, and Emmanuelle Conesa. 1999. "Corporate Governance, Innovation Systems and Industrial Performance." Industry and Innovation 6, 1: 25-50.

Wang, Clement K., Mao Qi, and Poh-Kam Wong. 2002. "The Effect of VC Industry Maturity on VC-Backed IPOs: Evidence from the U.S., Singapore 
and China." NUS Centre for Entrepreneurship Working Paper 2002/09/04, National University of Singapore.

Whitley, Richard. 1996. Continuity and Change in East Asian Capitalism: The Limited Effects of Internationalism and Domestic Change on the Business Systems of Japan, Korea, and Taiwan. Manchester: Manchester Business School.

. 2005. "How National Are Business Systems? The Role of States and Complementary Institutions in Standardizing Systems of Economic Coordination and Control at the National Level." In Changing Capitalisms? Internationalization, Institutional Change, and Systems of Economic Organization, ed. G. Morgan, R. Whitley, and E. Moen. Oxford: Oxford University Press.

Wong, Poh-Kam, Lena Lee, Yuen-Ping Ho, and Finna Wong. 2006. "Gobal Entrepreneurship Monitor 2005 Singapore Report.” NUS Entrepreneurship Centre, National University of Singapore.

Wyatt, Steve. 2006. "State of Innovation in Singapore: Some Findings of the IPS-Monitor Innovation Survey." Singapore Perspectives 2006. Singapore: Marshall Cavendish Academic. 


\title{
FIRSTFORUMPRESS
}

A Division of Lynne Rienner Publishers, Inc.

\section{China and the Energy Equation in Asia: \\ The Determinants of Policy Choice}

\author{
JeAn A. Garrison
}

CC arrison offers a nuanced

7 and cogent perspective on China's energy policy, setting it in an informative context of competing domestic stakeholders and a variety of significant foreign actors that affect Beijing's pursuit of its security, economic, social, and environmental agendas. Her book is essential reading on the subject."

-Steve Chan, University of Colorado

"Timely and insightful.... A fascinating exploration of the complex decisionmaking process and competing priorities of China's quest for energy security."

-Suisheng Zhao, University of Denver

CONTENTS: China's Search for Energy Security. Making China's Energy Policy. The "Great Game" in Central Asia. Pipeline Politics in East Asia. Challenges and Opportunities in Southeast Asia and Beyond. Juggling Priorities at Home. The Implications of China's Quest for Energy Security.

$2009 / 187$ pages hc $\$ 59.95$

1800 30th Street - Boulder, CO 80301 - Tel: 303-444-6684 - Fax: 303-444-0824 www.firstforumpress.com 